\title{
Design of a monitoring system for the cultivation of garden tomato in greenhouse
}

\section{Diseño de un sistema de monitoreo para el cultivo de tomate de jardín en invernadero}

\author{
Diana Elizabeth Minda Gilces ${ }^{1, *}$, Mayra Viviana Quispillo Guaranda ${ }^{1, \otimes}$, \\ Rene Cushpa Telechanca. \\ ${ }^{1}$ Universidad de Guayaquil. \\ \{diana.mindag@ug.edu.ec\}
}

Fecha de recepción: 21 de julio de 2017 - Fecha de aceptación: 31 de agosto de 2017

\begin{abstract}
This paper briefly discusses the design and implementation of a prototype that monitors temperature, humidity and ultraviolet solar radiation levels in a greenhouse set for the cultivation of garden tomato. The Scrum agile methodology was applied through the deployment of the prototype. The monitoring system is composed by low cost, commercially available sensors, a database and a computer program developed in JAVA. It provides charts, audible and visual alerts, as well as daily, monthly and yearly statistical reports of sensed data. Implementation in the greenhouse aids farmers in the decision- making process regarding crop exposure to the sun, water and ambient temperature, thus enhancing quality of the cultivation process.
\end{abstract}

Keywords-Sensor, Greenhouse, Temperature, Radiation, Humidity, Scrum.

Resumen-Este artículo discute brevemente el diseño e implementación de un prototipo que monitorea la temperatura, humedad y radiación solar ultravioleta en un invernadero para el cultivo de tomate de jardín. La metodología ágil Scrum se aplicó a través de la implementación del prototipo. El sistema de vigilancia está compuesto por sensores de bajo costos, disponibles en el mercado, una base de datos y un programa de computadora desarrollado en JAVA. Proporciona gráficos, alertas audibles y visuales, así como reportes estadísticos diarios, mensuales y anuales de datos detectados. Implementación en el invernadero ayuda a los agricultores en el proceso de toma de decisiones con respecto a cultivo de exposición al sol, agua y a temperatura ambiente, mejorando así la calidad del proceso de cultivo.

Palabras Clave-Sensor, Invernadero, Temperatura, Radiación, humedad, Scrum.

\section{INTRODUCTION}

$\mathbf{F}$ or over centuries agriculture has been the main revenue source of Ecuador's highland population. In Latin America, Ecuador is the second country with the largest number of family farms. (Reinoso, 2013) Agricultural activity accounts for about $29.3 \%$ of employment and generates a multiplier effect on the country's economic indicators. (telégrafo, 2017)

Environmental conditions determine, to a great extent, the viability and development of agricultural production; for this reason the application of agroclimatology in cultivation processes is considered fundamental to the fulfillment of quality standards. (International Center for Tropical Agriculture, 2015) Nevertheless, agricultural activity in Ecuador remains empirical. Farmers decide based on their experience, at what time and for how long to ventilate, irrigate and expose crops to the sun.These empirical measurements most of the time lack the accuracy that the garden tomato cultivation process requires to deliver a high quality product.

Garden tomato (lycopersicon lycoprsicum) is the second most important crop after potato in the global market (Ministerio de Agricultura, Ganadería, 2015). It can be cultivated in the open field or in greenhouses, the latter being the most common practice because it allows farmers

\footnotetext{
*Ingeniera en Telecomunicaciones, Máster of Science in Telecommunications and Networks

${ }^{\otimes}$ Ingeniera en Sistemas Computacionales
}

to extend the production cycle. The growth of tomato in a greenhouse, follows a strict procedure in which it is required to regulate the levels of temperature, humidity and solar radiation to which the crop is exposed in order to guarantee an ideal development of the plant(Lorenzo, 2012). The Ishikawa diagram in Figure 1 classifies the origins to the lack of crop monitoring in the greenhouse into three categories: technology, economy and human resource (labeled as farmers); causes are described in the left side andeffects on the right.

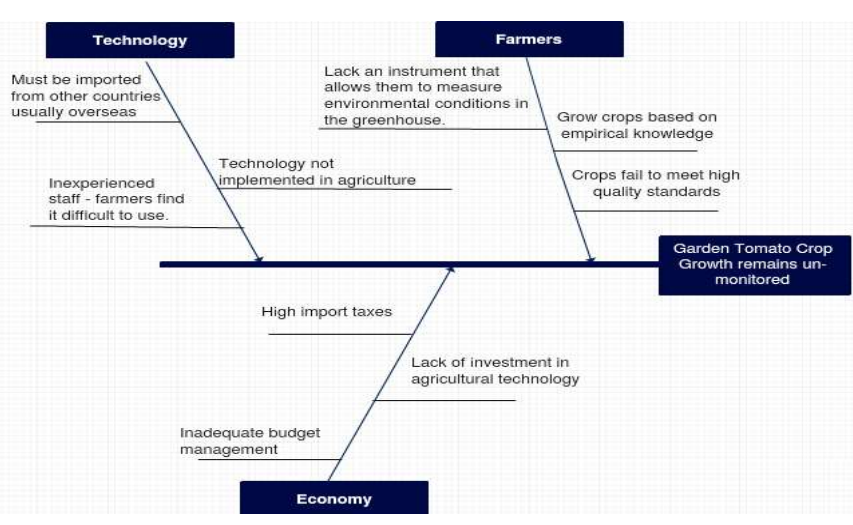

Figura 1. Ishikawa Diagram Fuente:Authors 
The main goal of this project is to develop the prototype of a system that monitors temperature, humidity and solar radiation of garden tomato crops in a greenhouse environment, in order to improve management of garden tomato quality standards. The proposal contemplates three specific objectives: to determine the impact of ambient temperature, humidity and solar radiation exposure in the cultivation process of garden tomato; to design the schematics of the monitoring system prototype, and to develop a software that provides an instrument to visualize, measure and adjust environmental conditions in the greenhouse.

\section{A. Analysis of the Effect of Environmental Conditions in the growth of Tomato Crops}

Growth stages of garden tomato can be split into five phenological stages: soil preparation, sowing, vegetative development, flowering and harvest. This section summarizes the information reviewed in documents Ministerio de Agricultura, Ganadería (2015) Lorenzo (2012) Campillo et al. (2012) regarding the impact of temperature, humidity and solar radiation in the cultivation process of garden tomato in three tables.

Temperature Effect:Ideal garden tomato development is closely related to ambient temperature. Table I describes the effect of three different temperature ranges in the cultivation of garden tomato in the greenhouse. Favorable temperature conditions are in the range of $16-24^{\circ} \mathrm{C}$

Tabla 1. Temperature Efect

\begin{tabular}{|c|c|c|}
\hline \multicolumn{3}{|c|}{ Temperature Ranges } \\
\hline Minimum $8-12^{\circ} \mathrm{C}$ & Optimal $16-24^{\circ} \mathrm{C}$ & Frecuencia \\
\hline $\begin{array}{l}\text { Nutrient intake and } \\
\text { growth processes } \\
\text { reach a minimum } \\
\text { intensity or stop. } \\
\text { If prolonged for } \\
\text { several days the } \\
\text { plant weakens. } \\
\text { Below this level the } \\
\text { plant undergoes } \\
\text { gradual decline } \\
\text { or death. }\end{array}$ & $\begin{array}{l}\text { All biochemical } \\
\text { processes } \\
\text { develop normally. } \\
\text { Vegetative growth, } \\
\text { flowering and } \\
\text { fruiting are } \\
\text { adequate. }\end{array}$ & $\begin{array}{l}\text { Excessive and } \\
\text { exhausting for the } \\
\text { plant, physiological } \\
\text { disorders are present } \\
\text { and flowering is } \\
\text { stopped. } \\
\text { When these } \\
\text { temperatures } \\
\text { are prolonged the } \\
\text { death of the } \\
\text { plant occurs. }\end{array}$ \\
\hline
\end{tabular}

Effect of Soil Moisture:Humidity is directly linked to the characteristics of the soil, the depth at which the tomato seedlings are planted and the type of water irrigation (Lorenzo, 2012). The agronomist must perform the necessary calculations to know the drip irrigation time that the crop should have. The main problems due to low or high humidity are described in Table II Effects of soil moisture in plant growth.

The agronomist must perform the necessary calculations to know the drip irrigation time that the crop should have. The main problems due to low or high humidity are described in Table II Effects of soil moisture in plant growth.
Tabla 2. Efect of Soil Moisture

\begin{tabular}{|c|c|}
\hline \multicolumn{2}{|c|}{ Soil Moisture } \\
\hline High Relative Humidity & $\begin{array}{l}\text { Low Relative Humidity } \\
\text { (at high temperatures) }\end{array}$ \\
\hline $\begin{array}{l}\text { Favors the development } \\
\text { of diseases and disorders } \\
\text { associated with a deficiency } \\
\text { of potassium, such as radial } \\
\text { or concentric cracks, cat } \\
\text { face or malformation, and } \\
\text { hollow fruits. }\end{array}$ & $\begin{array}{l}\text { This situation leads to } \\
\text { a higher rate of } \\
\text { transpiration and can } \\
\text { cause water stress, } \\
\text { increased root activity } \\
\text { and stomatal closure, } \\
\text { which reduces the } \\
\text { photosynthetic activity } \\
\text { of the plant and the } \\
\text { absorption of water and } \\
\text { nutrients. }\end{array}$ \\
\hline $\begin{array}{l}\text { In addition, fertilization is } \\
\text { hampered by compaction } \\
\text { of pollen and flowers may fall. }\end{array}$ & $\begin{array}{l}\text { Under these conditions, } \\
\text { the appearance of the } \\
\text { physiological disorder } \\
\text { known as apical rot or bud, } \\
\text { caused by calcium } \\
\text { deficiency,is favored. }\end{array}$ \\
\hline $\begin{array}{l}\text { Transpiration of leaves is } \\
\text { reduced which causes the plant } \\
\text { to move the absorbed water } \\
\text { towards the fruits, which } \\
\text { happens with so much pressure } \\
\text { that can cause the fruits to crack. }\end{array}$ & $\begin{array}{l}\text { Low relative humidity also } \\
\text { dries the pollen and } \\
\text { generates anomalies in } \\
\text { fertilization, it also produces } \\
\text { small, deformed and hollow } \\
\text { fruits. }\end{array}$ \\
\hline
\end{tabular}

Solar Radiation Effect: One of the main characteristics of a greenhouse setting is to minimize the exposure of the crops to solar radiation. Minimal exposure is considered an advantage, however if the greenhouse cover does not let in internal lighting, the tomato may present poor growth conditions. Table III, shows the effects of exposing tomato crops to low and high ultraviolet levels. (Lorenzo, 2012) (Campillo et al., 2012)

Tabla 3. solar Radiation Effect

\begin{tabular}{|c|c|}
\hline \multicolumn{2}{|c|}{ Exposure to Ultraviolet Radiation } \\
\hline Low Brightness & High Solar Radiation \\
\hline $\begin{array}{l}\text { Plants tend to insulate looking } \\
\text { forlight, stems weaken and } \\
\text { productionis decreased. }\end{array}$ & \\
\hline $\begin{array}{l}\text { Affects the processes of flowering } \\
\text { fertilization and vegetative } \\
\text { development of the plant, as it } \\
\text { reduces the viability of pollen, } \\
\text { limits evapotranspiration, and } \\
\text { reduces the absorption of water } \\
\text { and nutrients leading the plant to } \\
\text { a possible calcium deficiency, } \\
\text { known as apical rot of the fruit. }\end{array}$ & $\begin{array}{l}\text { An increase in ultraviolet-B } \\
\text { radiation due to anthropogenic } \\
\text { action can have a negative } \\
\text { impact on plants, causing a } \\
\text { decrease inphotosynthesis and } \\
\text { biomass production. }\end{array}$ \\
\hline $\begin{array}{l}\text { Increases the chances of hollow } \\
\text { fruits and maturation stained in } \\
\text { the tomato fruits. }\end{array}$ & $\begin{array}{l}\text { This radiation can also damage } \\
\text { indifferent biomolecules, among } \\
\text { which the most important is } \\
\text { DNA (deoxyribonucleic acid). }\end{array}$ \\
\hline
\end{tabular}

B. Related Work Similar research papers have been reviewed to conceive this document's proposal. The study in Tapia Espinoza and Zapata Freire (2012) exhibits the design and development of a prototype to control the temperature and humidity of a Bonsai tree nursery garden, based on the implementation of a PLC aimed at the control of data acquisition within a greenhouse, using an HMI located on a web server. The project in Marín et al. (2016) describes the control and supervision of variables in an irrigation and ventilation system to optimize the crops under greenhouse using sensors, actuators, PLC, automation, AS-I networks, and HMI. The project in Erazo Rodas and Sánchez Alvarado (2011) discusses 
the implementation of a wireless sensor network that allows monitoring environmental behavior, such as ambient temperature, relative humidity and solar radiation, for agricultural crops variables. The network consists of sensor nodes, which perform the measurements and are connected via the ZigBee protocol and the Global System for Mobile Communications / General Packet Radio Service (GSM/GPRS) technology to send information collected by the sensor nodes to a web server. Similarly, Cuji Coque and Pazmiño Moreno (2015) proposes the implementation of a Wireless Sensor Network based on ZigBee, WiFi and DigiMesh protocols to monitor ambient temperature, relative humidity and solar radiation in a garden tomato greenhouse.

\section{Methodology}

The monitoring system prototype is designed and tested in the Andean region of Izamba, a rural agricultural parish of 29.04 Sqm located $5 \mathrm{~km}$ north of central Ambato, a city in the Tungurahua province of Ecuador. This area is characterized by an irregular terrain with altitudes ranging from 2240 to 2680 masl. $80 \%$ of the soils of the parish are of agricultural use. Garden tomato crop accounts for $8.33 \%$ of total production areas. [11] The region is inhabited by approximately 120 expert garden tomato farmers.

The system's design and deployment is managed by the application of the Scrum framework. This methodology consists of various iterative processes used to address complex problems in software development and deliver high quality products. [12] A Scrum project begins by writing down a list of all the activities required for its development. These activities are organized into Sprints. A Sprint is a fixed "timebox" lasting usually a month or less during which a useable, potentially releasable product increment is created. A new Sprint starts immediately after the conclusion of the previous Sprint. Sprints are prioritized in what is known as a Product Backlog. A Product Backlog expresses product features in the form of user stories, which are short, simple descriptions of the desired functionality told from perspective of the user. Garden tomato farmers in the Izamba region were interviewed to collect system requirements in the form of user stories. Table IV shows the Product Backlog which organizes user stories into 4 different Sprints based on the feature to be incremented, its relevance, effort and amount of time needed to complete the activities. For instance, the goal with the highest priority is the design of the prototype schematics, with a relevance of 10. This user story is grouped together with the input module design into sprint 01. Combined, these two user stories make up a priority of 15 and the effort per hour does not exceed 30 which is set as the maximum effort per hour to be handled within a Sprint.
Tabla 4. Product Backlog

\begin{tabular}{|c|c|c|c|c|c|}
\hline \multicolumn{6}{|c|}{ Product Backlog } \\
\hline $\mathbf{N}^{\mathbf{0}}$ & User Story & Relevance & Effort & $\begin{array}{c}\text { Estimation } \\
\text { (hour) }\end{array}$ & Sprint \\
\hline 1 & $\begin{array}{l}\text { Design of } \\
\text { prototypes } \\
\text { chematics. }\end{array}$ & 10 & 5 & 10 & 01 \\
\hline 2 & $\begin{array}{l}\text { Input module } \\
\text { design }\end{array}$ & 5 & 3 & 6 & - \\
\hline 3 & $\begin{array}{l}\text { Components } \\
\text { integration } \\
\text { (Simulation) }\end{array}$ & 7 & 7 & 30 & 2 \\
\hline 4 & $\begin{array}{l}\text { Graphic Interface } \\
\text { Interface to } \\
\text { hardware }\end{array}$ & 8 & 7 & 30 & - \\
\hline 5 & Link Graphic & 5 & 3 & 10 & 03 \\
\hline 6 & $\begin{array}{l}\text { Visual and } \\
\text { Audio Alerts }\end{array}$ & 8 & 5 & 20 & - \\
\hline 7 & Reports & 7 & 7 & 40 & 04 \\
\hline
\end{tabular}

It is determined, based on the user stories in the Backlog that the prototype should consist of electronic components that read and/or measure environmental indicators in an analog or digital form. It is also required that the software provides user-friendly features such as: easy-to-use interface, graphical monitoring, visual and audible alerts and reports. Farmers required that these features must be implemented into independent software modules that provide simple ways for them to input and collect data to which allows them to forecast and manage the greenhouse environment in a more effective manner.

Each of the Sprints in the Backlog outputs a deliverable. For example, one of the deliverables in Sprint 02 is the design of the Input module. Circuit simulation software such as Proteus Design Suite, and Virtual Serial Ports Emulator (VSPE) are used to select the sensors and other electronic components that the Input Module is composed of. A Scrum Taskboard is executed per sprint to keep track of the Sprint progress. The design of the prototype's schematics is obtained once user stories numbers 1, 2 and 3 in Sprints 01 and 02 are completed. A. Prototype Design The monitoring system prototype is designed to meet the Input, Process and Output (IPO) model of the General Systems Theory. [13] Therefore, the prototype consists of three fundamental blocks as shown in Figure 1.

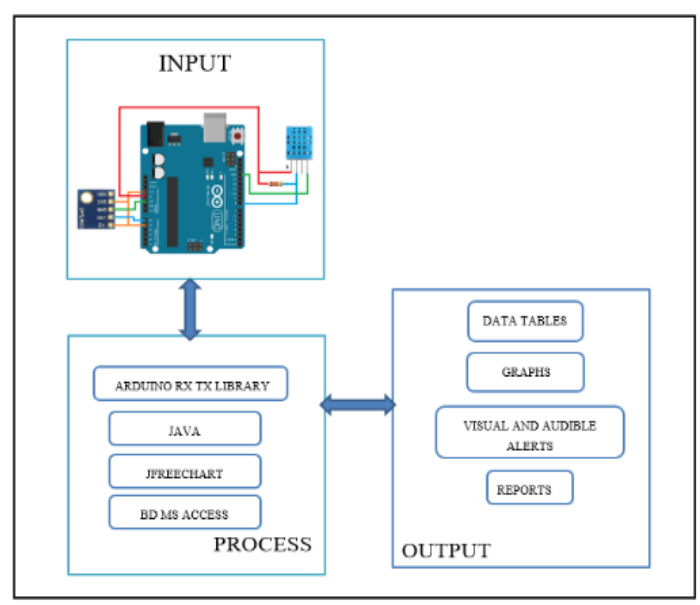

Figura 2. A block diagram representing the prototype. Fuente:Authors 
Hardware includes a digital computer, an Arduino Uno board, Temperature and Humidity Sensor DHT11 and Ultraviolet Sensor ML8511. A brief description of the hardware components is described below.

Arduino Uno: An Arduino board consists of an Atmel 8-, 16- or 32-bit AVR microcontroller with complementary components which helps in programming and other circuit incorporation. This board has a 5 volt linear regulator and a $16 \mathrm{MHz}$ crystal oscillator. (Chattoraj, 2015)

Temperature and Humidity sensor (DHT11): DHT11 uses a capacitive humidity sensor and a thermistor to measure the surrounding air, and spits out a digital signal on the data pin (no analog input pins needed). The only real downside of this sensor is one can only get new data from it once every 2 seconds.

Single-bus data format is used for communication and synchronization between microcontroller and DHT11 sensor.

One communication process is about $4 \mathrm{~ms}$.(Chattoraj, 2015) (D-Robotics UK, 2010)

Ultraviolet Radiation Sensor:The ML8511 is a UV sensor, which is suitable for acquiring UV intensity indoors or outdoors. It is equipped with an internal amplifier, which converts photocurrent to voltage depending on the UV intensity. It detects $280390 \mathrm{~nm}$ light most effectively. It outputs a analog voltage that is linearly related to the measured UV intensity $\left(\mathrm{mW} / \mathrm{cm}^{2}\right)$. (LAPIS Semiconductor, 2013)

Open Source software is selected to build the monitoring system prototype. This allows adequate compatibility between simulators, the JAVA programming language, the MS Access database and the Arduino Program Development Platform. The Netbeans IDE communicates with the Arduino through the use of RXTX libraries. (E. Bruno, 2016)

\section{System Prototyping}

This section provides an in-depth description of the functionalities of each of the system blocks labeled in Figure 2. It specifies the types and names of the sensors, their operation and the interaction between them and the microcontroller. The operational workflow of the system as a whole can is illustrated in Figure 3.

\section{A. Input}

The input stage is considered a subsystem Berttarlanfy (1986) it senses temperature, humidity and UV radiation. These data is gathered through the reading of sensors DHT11 and ML8511. The DTH11 measures ambient temperature and relative humidity whereas the ML8511 is the ultraviolet sensor. Data is then transmitted to the Arduino microcontroller via a wired signal. Analog voltage from the ML8511 is converted to digital by the microcontroller. This block also employs a method that allows the farmer to enter the thresholds (ranges) for the three environmental variables: temperature, humidity and ultraviolet radiation.

\section{B. Process}

The backbone of the system consists of a software developed in a NetBeans IDE using the Java programming language to receive information from the input module in order to process, interconnect and generate different outputs according to the system operators' request.
This software is installed in a computer that will receive the data from the input module to monitor temperature, humidity and solar radiation.

The main operations of the processing block are to:

1. Read data from the input module

2. Draw statistical graphs

3. Generate visual and audible alerts.

4. Handle database connection processes.

Data generated by the Arduino Uno microcontroller is received from the input module through a wired serial connection and interpreted by using the code in the RXTX library.

Sensed data entry is handled by a listening class. Incoming port access is based on an event-based model. When a monitored serial port status changes during runtime, the software initiates a serial event on the registered serial port receiver. This information is buffered, values are averaged and then stored in the MS Access database.

The graphing class uses the JFreeChart Library to generate professional quality charts in a JFrame. (Gilbert, 2016) Three statistical graphs displaying temperature, humidity and UV radiation measurements are created as Time Series Charts. DialCharts (clock meter like graphs) display the most recent sensed data in real time. Within the graphing class, a method generates visual and audible alerts. Whenever one or more of the environmental indicators have exceeded the thresholds, a semaphore-like signal turns red and an audio-clip is played to alert the farmer that instantaneous action needs to be taken in the greenhouse regarding ventilation, irrigation and /or exposure of the garden tomato crop.

The reporting class queries the MS Access Database to generate daily, weekly and monthly statistical reports of the levels of temperature, humidity and solar radiation to which the crop is exposed. These reports can be printed so that farmers can keep record of this statistical data and apply it in future garden tomato growth processes. The data also feedbacks the monitoring system parameters through the feedback block.

\section{Output}

The various operations in the process produce several outputs, listed as follows:

1. An audible alarm is triggered when the measurement of temperature, humidity and radiation, is out of bounds when compared to those parameters established by the user.

2. The visual semaphore-like alert turns red when sensed data is out of bounds.

3. The system displays real-time data in graphical form. It also shows the data in real time per environmental indicator.

4. The program displays the data on a daily, monthly andannual basis.

5. Provides daily, monthly and annual reports. 


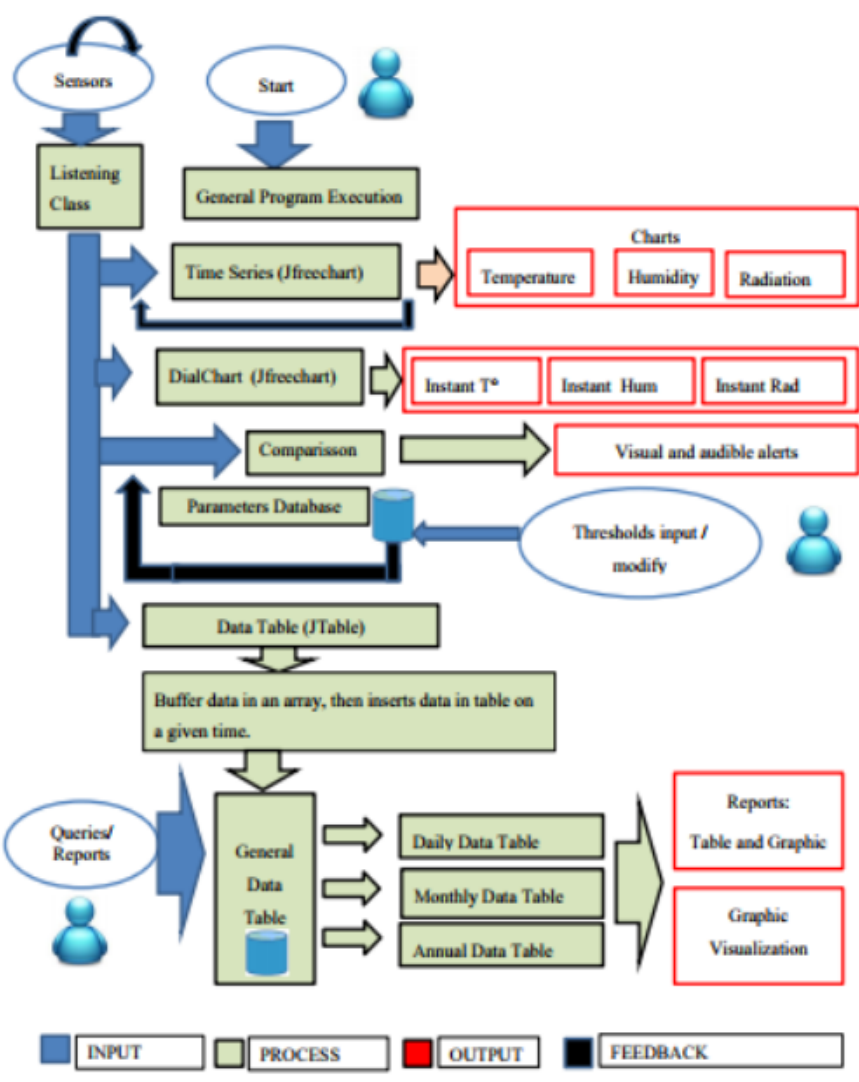

Figura 3. Detailed workflow between system blocks.

Fuente:Authors

D. Feedback A very important characteristic of the systemic model regarding communication and interaction of the system is feedback.

Within the Process block there are several sub processes that perform diverse activities based on output data. This data is reprocessed to:

- Update the MS Access Database.

- Update averaged measurements within a table.

- Use listening class to update input data. (every 7 seconds).

- Update charts in the graphical interface.

\section{Evaluation of Results}

The proposed design of a monitoring system for the cultivation of garden tomato in greenhouse is proved through Quality Assurance Tests (QAS) and User Acceptance Tests (UAT). The aim of the Quality Assurance Test is to avoid User Acceptance Tests are executed after QATs, and tryout the prototype's effectiveness in enhancing the garden tomato cultivation process. A total of 20 expert farmers where asked to test the proposed solution.

A. Quality Assurance Tests Quality Assurance consists of a set of systematic processes applied to monitor the software engineering methods used to ensure quality H. L. Johnson (2011). In this project, quality assurance is validated through test cases. A test case is designed for sprints 02,03 and 04 . Each of the test cases consists of an objective, and action and an expected result. The strategy consists of planning tests cases with clear objectives, in which the precondition of the system, the action to be taken and the expected results can be easily described. The results must be visually measurable so that they can be compared to the expected results and prove its performance.

Twenty expert farmers were asked to participate in the execution of the test cases. After each test is performed, the outcome is examined by 2 expert farmers and 2 programmers.

Table $\mathrm{V}$ displays the information of three of the six test cases that performed to guarantee the quality of the monitoring system prototype.

Tabla 5. Test Cases

\begin{tabular}{|c|c|c|c|}
\hline \multicolumn{4}{|c|}{ Test Cases } \\
\hline $\begin{array}{l}\text { User } \\
\text { Story } \\
\text { No }^{0}\end{array}$ & Objective & Action & Expected Results \\
\hline 3 & $\begin{array}{l}\text { Sensors transfer } \\
\text { sensed data. }\end{array}$ & $\begin{array}{l}\text { Proteus schematics } \\
\text { and VSPE } \\
\text { simulate data } \\
\text { readings. }\end{array}$ & $\begin{array}{l}\text { Prototype's } \\
\text { measurements } \\
\text { resemble those } \\
\text { in the simulation. }\end{array}$ \\
\hline 6 & $\begin{array}{l}\text { Audible alarms } \\
\text { are generated. }\end{array}$ & $\begin{array}{l}\text { Operator sets data } \\
\text { out of bounds } \\
\text { on purpose. }\end{array}$ & $\begin{array}{l}\text { System emits a } \\
\text { sound once } \\
\text { parameters are } \\
\text { set out of bounds. }\end{array}$ \\
\hline 7 & $\begin{array}{l}\text { Test Statistical } \\
\text { Reports } \\
\text { Generation }\end{array}$ & $\begin{array}{l}\text { Operator chooses } \\
\text { to view a daily, } \\
\text { monthly or } \\
\text { annual report. }\end{array}$ & $\begin{array}{l}\text { A statistical report } \\
\text { is generated based } \\
\text { on the selected } \\
\text { choice. }\end{array}$ \\
\hline
\end{tabular}

Product acceptance is rated according to weighted criteria regarding the outcomes of each test case.

- Sensed data. Variable thresholds are input into the system. Levels of environmental indicators are measured and graphed. An audible alarm is heard when thresholds are exceeded. Semaphore alert is generated when thresholds are exceeded. Data control reports are generated

A fully accurate execution or measurement of the test case is weighted 3 points. A precise execution/measurement is worth 2 and an erroneous execution/measurement weighs 1 . Table VI displays the outcome of each Quality Assurance test case, the total weighted score and the percentage of success, which expresses the degree of resemblance of the outcome vs the expected result. All of the outcomes score above $80 \%$ success rate, proving that all of the functionalities in the monitoring system prototype working as expected and meet the requirement criteria.

Tabla 6. QA Results

\begin{tabular}{lccc}
\hline \multicolumn{1}{c}{ Outcome } & $\begin{array}{c}\text { Maximu } \\
\text { Weighted } \\
\text { Score }\end{array}$ & $\begin{array}{c}\text { Total } \\
\text { Score }\end{array}$ & $\begin{array}{c}\% \\
\text { Success }\end{array}$ \\
\hline $\begin{array}{l}\text { Data is sensed } \\
\text { Environmental } \\
\text { Tresholds are set }\end{array}$ & 12 & 11 & $91.67 \%$ \\
$\begin{array}{l}\text { Graphing measures of } \\
\text { environmental indicators } \\
\begin{array}{l}\text { Audible alert heard when } \\
\text { indicators are set out of bounds }\end{array}\end{array}$ & 12 & 11 & $91.67 \%$ \\
$\begin{array}{l}\text { Semaphore-like alert will } \\
\text { be displayed when indicators } \\
\text { are setout of bounds }\end{array}$ & 12 & 10 & $83.33 \%$ \\
$\begin{array}{l}\text { Statistical Monitoring } \\
\text { Reports aregenerated }\end{array}$ & 12 & 11 & $93.33 \%$ \\
\hline
\end{tabular}


B. User Acceptance Tests User Acceptance Tests are meant to prove that the monitoring system prototype does what it was meant in spirit to accomplish and that it is aesthetically how it is supposed to work (H. L. Johnson, 2011). During a full month the same group of 20 expert farmers that executed the QATs used the monitoring system prototype to measure the degree of exposure of the garden tomato crops to ambient temperature, humidity and ultraviolet radiation in a real time setting. They relied on the prototype's graphical measurements and alarms to decide the time intervals in which garden tomato crops should be ventilated, irrigated and exposed to the sun.

The application of the monitoring system prototype generated an assisted decision making process in the cultivation of garden tomato. Farmers stopped guessing or depending on empirical knowledge or previous experience to monitor and regulate environmental conditions in the greenhouse. Instead they now use the easy-to-use, friendly user interface provided by the monitoring system to forecast and prepare the environmental conditions of their garden tomato crops. Figure 4 shows environmental variables being sensed in real time in Time Series charts and DialCharts as well as the visual alarms for each of the measurements, in this case humidity is above the accepted threshold and the semaphore alarm for this variable is red.

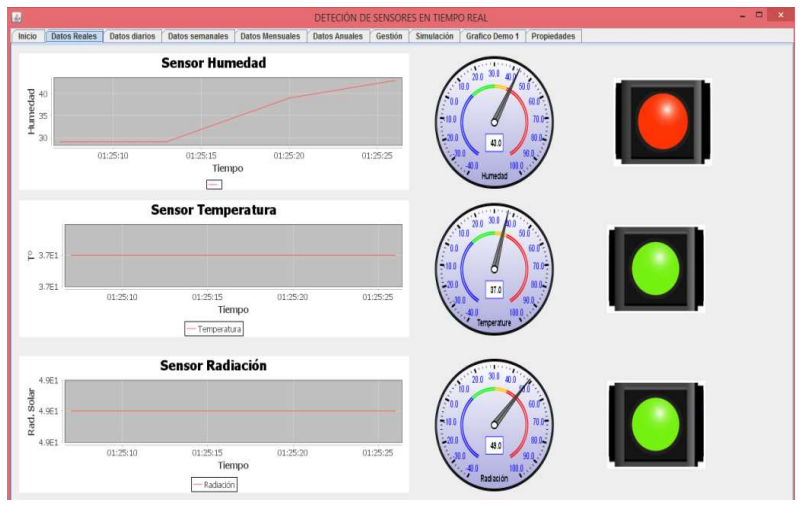

Figura 4. Real-time environmental variables sensing.

Fuente:Authors

Participants were presented a 10 question survey regarding the impact of the use of the monitoring system prototype. The questions intend to determine the monitoring system ease of use and to compare and contrast the effectiveness of cultivating garden tomato with and without the system in terms of confidence and product quality.

Table VII presents the results of the survey. Efficiency percentages for regular cultivation process are labeled RC\% and monitored cultivation process are labeled as MC\%. Note that prior to the prototype's implementation none of the activities involved in the cultivation of garden tomato were performed by farmers with a confidence degree which exceeds $30 \%$ certainty. Contrarily, with the use of the monitoring system prototype the least degree of certainty is of $80 \%$. It is important to notice the percentages for Enhanced Crop Care and General Decision Making, which reflect how the farmers perceive garden tomato crops are influenced by the application of either one of the cultivation methods, this is, without (RC \%) and with $(\mathrm{MC} \%)$ the monitoring system.

Tabla 7. UAT Results

\begin{tabular}{lcc}
\hline \multicolumn{1}{c}{ Process } & RC ( \%) & MC ( \%) \\
\hline Ventilation & 20 & 100 \\
Water Irrigation & 20 & 90 \\
Covering or Exposing to Sunlight & 10 & 80 \\
Enhanced Crop Care & 30 & 80 \\
General Decision Making & 30 & 90 \\
\hline
\end{tabular}

\section{Conclusions}

The prototype's design successfully fulfills the operational requirements of the system and increases the efficiency and certainty with which the farmers monitor and adjust environmental conditions in the greenhouse. The accuracy of the design is achieved as a result of the precise information gathering provided by user stories and the literary review of similar research studies that are also setup in Ecuador or neighboring countries in South America. The Scrum methodology proves effective in the selection of electronic components, their integration through software engineering and the prototype's deployment. For instance, the adoption of the DTH11 sensor has an advantage over other equipment, given the fact that it measures two of the environmental variables (temperature and humidity) at once and outputs the sensed signal as digital data. This allows for improved integration with the Arduino microcontroller and manufacturing cost reduction, as only one sensor is bought and configured for the prototype's deployment. Regarding solar radiation sensor ML8511, the principal benefit of using it over other sensors is the high degree of measuring that it provides. Adequate software engineering is accomplished through the implementation of open source technology, including simulation software and libraries correctly aimed at meeting farmers' requirements of friendly, easy-to-use interfaces. In turn, the input module is properly blended with the process and output blocks to improve general decision making processes and enhancing crop care as proved by QASs and UATs. This implies that the monitoring system provides a simple, practical, low cost technological tool that could strengthen agricultural processes in Ecuador. Future work should address the automation of the ventilation, irrigation and solar exposure activities involved in the cultivation process of garden tomato crops.

\section{BIBLIOGRAPHY}

Berttarlanfy, L. B. (1986). Foundations Development, Applications (Revised Edition), New York: Penguin University Books.

Campillo, C., Fortes, R., and del Henar Prieto, M. (2012). Solar radiation effect on crop production. In Solar Radiation. InTech.

Chattoraj, S. (2015). Smart home automation based on different sensors and arduino as the master controller. International Journal of Scientific and Research Publications, 5(10):1-4.

Cuji Coque, D. E. and Pazmiño Moreno, D. X. (2015). Diseño e implementación de una red wsn (wireless sensor network) 
basado en los protocolos zigbee, wifi y zigbee mesh, para el monitoreo de variables climáticas en el invernadero ubicado en el barrio rumipamba del navas, cantón salcedo, provincia de cotopaxi. B.S. thesis, Universidad de las Fuerzas Armadas ESPE Extensión Latacunga. Carrera de Ingeniería en Electrónica e Instrumentación.

D-Robotics UK (2010). "DHT11 Humidity \& Temperature Sensor,” DRobotics UK, London.

E. Bruno (2016). "Dr Dobbs The World of Software Development," 13 November 2013. [Online]. Available: http://www.drdobbs.com/jvm/control-an-arduinofromjava/240163864.

Erazo Rodas, M. L. and Sánchez Alvarado, J. L. (2011). Control y supervisión de variables en un sistema de antiheladas, regadío y ventilación para optimizar los cultivos bajo invernadero. B.S. thesis, Latacunga/ESPE/2011.

Gilbert, D. (2016). "JFree org," [Online]. Available: http://www.jfree.org/jfreechart/.

H. L. Johnson (2011). The Elements of Scrum, Foster City, California: DYMaxicom.

International Center for Tropical Agriculture (2015). Climatesmart tools for Latin America. Climate Change Agriculture and Food Security.

LAPIS Semiconductor (2013). "ML8511 UV Sensor with Voltage Output".

Lorenzo, P. (2012). El cultivo en invernaderos y su relación con el clima. Cuadernos de Estudios Agroalimentarios (CEA), (3):23-44.

Marín, M. R., Padilla, L. S., and Gómez, J. G. (2016). Sistema de monitoreo agrícola mediante redes inalámbricas de sensores para el monitoreo de variables ambientalessismoagro. Ingenieria al Dia, 2(2).

Ministerio de Agricultura, Ganadería, A. y. P. (2015). "Boletín Situacional Tomate Riñón.," Quito, Ecuador.

Reinoso, D. (2013). Programa cohesión territorial para el desarrollo/boletín no 1, enero 2013.

Tapia Espinoza, L. M. and Zapata Freire, D. E. (2012). Diseño y construcción de un prototipo para control de temperatura y humedad de un vivero de árboles bonsáis. B.S. thesis, QUITO/EPN/2012.

telégrafo, E. (2017). El agro concentra el 29,3\% de empleos en el país. 